\title{
Significance and Relevance of the Leadership Qualities, Ideals and Values of Mahatma Gandhi, in Sustaining Successful Businesses in Today's World
}

\author{
Swaroop Simha
}

\begin{abstract}
Keep your thoughts positive because your thoughts become your words. Keep your words positive because your words become your behaviour. Keep your behaviour positive because your behaviour becomes your habits. Keep your habits positive because your habits become your values."-Mahatma Gandhi

The word Mahatma refers to the great soul. It is not an title that gets worldwide approval and acceptance for a title given to an individual who was known for not just his simplicity, but a man who lived to leave behind a legacy which none has ever attempted to occupy or can ever hope for.

Mohandas Karamchand Gandhi, commonly known as Mahatma Gandhi, was the preeminent leader of Indian nationalism in British-ruled India. Employing non-violent civil disobedience, Gandhi led India to independence and inspired movements for non-violence, civil rights and freedom across the world. His thoughts on wide ranging areas extends from politics, to spirituality, business and economics, poverty, suffering, love, non-violence, civil disobedience, and many more areas ,besides his own life all have a great message and learning for humanity.
\end{abstract}

The paper is important, from the point of view, for understanding the modern generation, post-independence India, globalization, and a review of the current values attitudes and lifestyles and their relevance to Business management.

The paper is an empirical qualitative research study and provides insights into the existing levels of awareness in the form of theoretical and conceptual reflections in understanding one man's ideals values and principles practiced nearly seven decades ago. In-depth interviews and focus groups was conducted for exploring to see if such values and principles are relevant and effective even to this day.

Dr. Martin Luther King, Jr said. "Gandhi was inevitable. If humanity is to progress, Gandhi is inescapable... We may ignore him at our own risk."

These words reflect Dr. Martin Luther King Jr's heart felt respect for Mahatma Gandhi.

Index Terms-Leadership, qualities, ideals, values, management concepts, sustaining, modern businesses.

\section{INTRODUCTION}

According to Keith Davis, "Leadership is the ability to persuade others to seek defined objectives enthusiastically. It is the human factor which binds a group together and motivates it towards goals."

Today's global business environment is very unpredictable and complex. There is a need for good leadership in businesses to succeed. More than contextual factors such as economic conditions, industry factors, and firm's overall health, leadership factors now have a much more predictive impact on company performance. A study showed that quality of those in management positions accounted for at least $70 \%$ of employee engagement while exceptional leaders can contribute about $48 \%$ higher profit than average managers. Therefore, one of the most important decisions a company can make is to find out, who to appoint to positions of authority. [1]

To be an agent for change requires many qualities and behaviors. It requires mastery of one's self, and an understanding of the uncertainty of their environment and the complexity of relationships with other people. While there is a belief some are born to lead, the fact is that the skills and beliefs required to lead others can be applied, practiced and perfected by anyone with the sincere desire to do so. To know if one is a good leader or whether one has the qualities to become one, managers need to honestly answer questions about themselves.

\section{PURPOSE}

The purpose of this study is to explore the level of awareness and understanding one of India's greatest leaders the world has ever known, the relevance and significance of his ideals and values as a role model even to this day and its application to businesses to become successful. The purpose is to help us get an insight into the mind-set and thinking of new age Indian youths and young adults alike.

\section{THE OBJECTIVE}

To study and understand the significance of Mahatma Gandhi's leadership qualities, ideals and values and its relevance to the field of Business Management.

\section{RESEARCH DESIGN}

Qualitative research design has been applied involving Interviews, focus groups, and a small-scale survey across a cross section of Business management students, practitioners and academicians to collect information about leadership and connect it to "Ghandian perspective". [2], [3]. 


\section{ABout MaHATMA GANDHI: THE MAN, THE LEADER, AND THE MOVEMENT}

If one was to ask who is a leader? And look at history of India one individual made a mark as a Leader capturing the imagination of millions of people not just in the country of his origin but all over the world and that was Mohandas Karamchand Gandhi. He came to be known as Mahatma meaning 'Great Soul'. He was an astute political campaigner who fought for Indian independence from British rule and for the rights of the Indian poor. The word Mahatma is not an title that gets worldwide approval and acceptance, it is a title given to an individual who was known for not just his simplicity, but a man who lived to leave behind a legacy which none has ever attempted to occupy or can ever hope for.

The son of a senior government official, Gandhi was born and raised in a Hindu Bania community in coastal Gujarat and trained in law in London. Gandhi became famous by fighting for the civil rights of Muslim and Hindu Indians in South Africa, using new techniques of non-violent civil disobedience that he developed. Returning to India in 1915, he set about organizing peasants to protest excessive land-taxes. A lifelong opponent of "communalism" (i.e. basing politics on religion) he reached out widely to all religious groups. He became a leader of Muslims protesting the declining status of the Caliphate. Assuming leadership of the Indian National Congress in 1921, Gandhi led nationwide campaigns for easing poverty, expanding women's rights, building religious and ethnic amity, ending untouchability, increasing economic self-reliance, and above all for achieving Swaraj - the independence of India from British domination.

Gandhi began his activism as an Indian immigrant in South Africa in the early 1900s and in the years following World War I became the leading figure in India's struggle to gain independence from Great Britain. He was known for his ascetic lifestyle-he was dressed only in a loincloth and shawl-and devout Hindu faith, Gandhi was imprisoned several times during his pursuit of non-cooperation and undertook a number of hunger strikes to protest the oppression of India's poorest classes, among other injustices.

As part of his nonviolent non-cooperation campaign for home rule, Gandhi stressed the importance of economic independence for India. He particularly advocated the manufacture of khaddar, or homespun cloth, to replace imported textiles from Britain. Gandhi's eloquence and embrace of an ascetic lifestyle based on prayer, fasting and meditation earned him the reverence of his followers, who called him Mahatma (Sanskrit for "the great-souled one"). Invested with all the authority of the Indian National Congress (INC or Congress Party), Gandhi turned the independence movement into a massive organization, leading boycotts of British manufacturers and institutions representing British influence in India, including legislatures and schools. [4] (M. K. Gandhi (1929) An Autobiography or the story of my experiments with truth, Navajivan publishing house).

\section{THE STUDY AND THE OUTCOME}

The study was designed using Qualitative research technique. This included interviewing Heads of the
Institutions (Like CEO's, Principal, HOD'S) both in the Industry and educational sectors, and focus groups and small scale quantitative survey was conducted with young adults for validation and understanding of the level of, awareness of Ghandian perspectives, pertaining to leadership qualities, ideals, values and its relevance to present day world necessary to run successful businesses.

The participants voiced and gave their views about Gandhi and his leadership qualities with genuine admiration and without any prompt or bias from the interviewer.

\section{A. In Depth Interviews}

CEOS and Heads of the Institutions discussed the importance of leadership at length in the one on one interview.

There was mention about John Maxwell and his thoughts about leadership "Being a great leader is all about having a genuine willingness and a true commitment to lead others to achieve a common vision and goals through positive influence. ... Leadership is about people-and for people".

And when asked about their views about Mahatma Gandhi they were in unison to agree that he was a great leader and a role model, who had strong ideals and values, and they are good qualities every leader should possess.

Only one CEO disagreed about the significance of Ghandian qualities, Ideals, values being relevant in today's business world, while the other three participants in the one on one interview felt and agreed whole heartedly that it is significant and very relevant this day and the days to come.

\section{B. Focus Group with Young Adults}

Two focus groups with young adults (Age group 22-25yrs) was conducted, some of them had experience of working in a business firm and all the others pursuing Management education, were asked to talk about Leadership, significance of leadership, leadership qualities necessary to lead successful businesses, and finally they were asked to think about role model leaders. Strangely, in both the focus groups, Mahatma Gandhi was a name which came up impromptu and the participants who had not thought about him actually were found to warm up to the idea of him as a great leader, once they started discussing about the topic of leadership, it was very evident, that the participants (Young Adults), found qualities, ideals, values of Mahatma Gandhi very significant, relevant and essential for becoming a great leader in the modern times.

\section{Small Scale Quantitative Survey}

A survey using unstructured and open-ended questionnaire was distributed to 20 respondents. This was meant to validate some of the views obtained in the Interview and Focus group. The questions were meant to be reflections of the respondents' thoughts, about Gandhi and Ghandian qualities, ideals, values asked as open-ended questions. Also, in the questionnaire was a section dedicated to quiz about Gandhi's famous quotes and which gave meaning and understanding for the respondents was covered.

The participants in the interview, focus group and the survey, had out of their own free will, chosen Mahatma Gandhi as a leader with qualities which according to them were most admirable ones but also what made the man a great 
leader.

\section{Usage of Mahatma Gandhi's Quotes}

Throughout the research, in all the three formats used to collect the data from the participants, the researcher deemed it important to use and refer to some of the famous quotes by Mahatma Gandhi. These quotes from Mahatma Gandhi facilitated in understanding its true meaning. It was a source of motivation in getting an insight of the man "Gandhi" was and about his thinking. And hence it has been used widely in this study to connect to leadership in business management.

Presented below are the outcomes of research based on the interaction and data collected through interviews, focus groups and small-scale quantitative survey conducted, summarized in terms of qualities, ideals values, which are found to be relevant for leading successful businesses in the present times.

There were many qualities, ideals and values identified however the most important ones have been listed below, and these were those which had a consensus by all participants. It is presented as a compilation of seven most important qualities for a leader to succeed, drawing parallel to Mahatma Gandhi's qualities, ideals and values it is supported by famous quotes. They are listed below as follows:

1) Mahatma Gandhi lead by example: "Be the change

that you wish to see in the world."

Gandhi's greatest quality was to walk his talk in every way and at every level. Gandhi practiced what he preached by dressing up like the poorest Indian and having the barest of minimum personal possessions. He portrayed simplicity in leaving, but high level of thinking.

All the participants were very clear and vociferous in voting for this quality as being most important one; A leader should be a role model to his followers. A leader must lead by example to the most possible extent.

Through simple small ways, leader can exemplify their leadership by putting their individual interests after the organization's interest and following the ideas they propagate.

2) Mahatma Gandhi believed in a strong value system:

"Happiness is when what you think, what you say and what you do, is in harmony"

Mahatma Gandhi was a man who believed in action with ideas stemming from his value system. He applied his values of 4 E's: Envision, Enable, Empower, and Energize to make his life great. Mahatma Gandhi had a rock-solid value system which led to the inception of his ideas. He said, "To believe in something and not live it is dishonest". He aspired to make positive and productive changes in his life at every turn and had a completely interdependent relationship with his followers.

This perspective was widely accepted and believed by participants especially in the interview segment, the above quote lays great emphasis to it. A good leader needs first of all have a strong value system.

3) Mahatma Gandhi was very astute and persistent:

"Live as if you were to die tomorrow. Learn as if you were to live forever."

A critical success for Gandhi was garnering the right kind of support from the nation and from the international community. He could achieve this primarily due to his extraordinary persistence and articulation of his vision and his methods. His determination to follow through his preaching was often at the cost to his own health but that didn't deter him from his struggle. His march to Dandi to protest the tax on salt is an epitome of his persistence in following non-violence. He started his walk alone and the nation followed him.

The need to be steadfast in achieving goal by a leader has been associated with the above quality, according to the participants in the study, A leader should be visionary, he should visualize future and should persist to achieve it.

4) Gandhi's ability to strategize: "The future depends on what you do today."

All the people interviewed believed Mahatma Gandhi was a "Brilliant Strategist" He was even termed as a showman, by one CEO, As a man whose actions was based on "Thinking of the moment"( as quoted by one CEO of a software firm) but all participants agreed that When Gandhi returned from South Africa, He travelled the length and breadth of India, by train and road, He saw and understood what was the essence of India, he understood agriculture was predominant and the farmers were simple people and also the most exploited. A leader in business must, excel in his field, he must constantly learn, develop and grow to rally support from his followers.

5) Mahatma Gandhi reinvented according to the situation: "Freedom is not worth having if it does not include the freedom to make mistakes."

In situations where all the existing methods and tactics had failed, Gandhi reinvented the rules of the game to deal with tricky situations. He broke tradition and followed unconventional approach like non-violence and Satyagraha to deal with the British when he realized that brute force won't help. Resource constraint did not deter him as he believed to have the courage to invent the means. He advocated having leadership styles that were circumstances dependent to use relevant and effective approach to deal with a problem.

One of the respondents called him an inventor, an indigenous engineer. He showed the world what a "Charka" could do; it was a symbolic act, of self-sufficiency and independence. A leader is needed to be innovative and creative in his thinking. The participants also felt a leader must have boldness and quick thinking, to handle uncertain situations.

6) Mahatma Gandhi a leader who could communicate and influence: "Man often becomes what he believes himself to be. If I keep on saying to myself that I cannot do a certain thing, it is possible that I may end by really becoming incapable of doing it. On the contrary, if I have the belief that I can do it, I shall surely acquire the capacity to do it even if I may not have it at the beginning. "'

Mahatma Gandhi had a great ability to communicate and what he communicated had a powerful impact on the masses his ideals values and principles were decimated to the masses like wild fire. Mahatma Gandhi as a leader worked on remarkable public relations network and developed right relationship with the press. He created the right impact with his activities and understood the human psyche which helped him with his public relations. His speech in South Africa 
where he showed first signs of activism is recalled by many respondents in the course of this study. A leader needs to motivate the followers with the right words. According to, one head of an institute, Gandhi was born to create a difference in this world.

7) Mahatma Gandhi as an ordinary man with extraordinary humanness: "You must not lose faith in humanity. Humanity is like an ocean; if a few drops of the ocean are dirty, the ocean does not become dirty."

As a man Gandhi accepted all his flaws and never hid them, he also accepted that people made mistakes, and he believed in the power of forgiveness. He said, "An eye for an eye will only make the whole world blind." And he also believed. "The weak can never forgive. Forgiveness is the attribute of the strong". This makes him a very humane individual. His ability to understand and connect with people and transform peoples thinking without any force, by exhibiting simple humane values is a remarkable quality, and it was recognized by all the participants in this study. The participants felt a good leader must be humane first, by this; he will gain the respect and admiration of his followers.

\section{LEARNING AND CONCLUSION}

Studies about Leadership have become so important in recent years, because the business world has become more competitive and more volatile. [5] Major changes are more and more necessary to survive and compete effectively in this new environment. More change always demands more leadership. [6]

Lot has been written and studied about the differences between Management and Leadership. John P. Kotter in his books -The leadership Factor (Free press 1988) and A force for change: How Leadership Differs from Management (Free Press 1990) quotes "Management is about coping with complexity, Leadership, by contrast, is coping with Change" [7], [8].

Companies manage complexity first by planning and budgeting- setting targets or goals for the future. By contrast, leading an organization to constructive change begins by setting direction- The word organizing people need be changed to aligning towards a direction.[6] Well led businesses tend to recognize and reward people who successfully develop leaders to facilitate, in developing a vision of the future along with strategies for producing the changes needed to achieve that vision. This requires aligning people, communicating the new directions to those who can create coalitions that understand vision and are committed to achievement.

In an article "What Titans can Teach us" by Richard S. Tedlow (Harvard Business Review) Focusing on the experiences of seven great innovators, the author argues that many of their traits are replicable by mere mortals. A handful of simple principles were woven into their lives: whether they led through inspiration or intimidation, a clear mission and consistent messages were keys to making their dreams reality. So were a limitless sense of what they had to offer and unflinching commitment to the fulfillment of their destinies. [9]
Their certainty in the face of uncertainty, skepticism, and even ridicule was a beacon for attracting and motivating followers. [9]This also rings very true when one thinks of Mahatma Gandhi's traits and values.

\section{A. The Great Man Theory of Leadership}

Based on the work of the historian Thomas Carlyle, states that some people are born with the necessary attributes that set them apart from others and that these traits are responsible for their assuming positions of power and authority. A leader is a hero who accomplishes goals against all odds for his followers. The theory implies that those in power deserve to be there because of their special endowment. Furthermore, the theory contends that these traits remain stable over time and across different groups. Thus, it suggests that all great leaders share these characteristics regardless of when and where they lived or the precise role in the history they fulfilled. [10], [11], [12]

\section{B. One Man Who Still Inspires the World}

Mahatma Gandhi has been an invaluable brand from India. As a leader he has inspired many other leaders who have persevered for the improvement of humankind. Gandhi's actions inspired future human rights movements around the globe, including those of civil rights leader Martin Luther King Jr. in the United States and Nelson Mandela in South Africa.

Mahatma Gandhi \& his leadership ideals and values can be termed as timeless and relevant to all working professionals. His qualities include a naturally charismatic leadership which inspires millions even after 70 years from his death. In 1947, Gandhi's ideology and its application were cardinal in India's fight for independence. He was both a transformational and a transactional leader which was the prime reason for his lasting impact on the struggle for Indian Independence.

The greatness of Gandhi can be ascertained from the fact that over 100 nations released a stamp of Mohandas K Gandhi (1869-1948). For leaders and managers who wish to have an inspiring leadership style, Gandhi ideas, ideals and values can be emulated.

Gandhi's success and sustained reputation makes him a leader worthy to follow and seek inspiration from. He always advised people to lead authentically for the greater good.

In conclusion, Gandhi's relevance is more significant today as many leaders in business are educated, articulated and ambitious but lack the right value and virtue system. In present times, to lead, managers should not only have the right skills but also a vision for themselves and for others and have the right attitude to achieve their goals. [13]

\section{REFERENCES}

[1] A. J. Durbrin, Leadership-Research Findings, Practice, and Skills, 4th ed. Biztantra, 2007.

[2] B. Taylor and S. Ghoshal, "Research methodology - A guide for management and social sciences," PHI.

[3] C. Schindler, Business Research Methods, McGraw-Hill, 8th ed.

[4] M. K. Gandhi. An Autobiography or the Story of My Experiments with Truth, Navajivan Publishing House, 1929.

[5] G. Yuk1, Leadership in Organizations, 6th ed. Pearson Education.

[6] J. C. Maxwell, Developing the Leader within You, (2.0), Harper Collins: Kindle Edition, 2018.

[7] P. John, Kotter What Leaders Really Do, HBR Onpoint Edition, [Online]. Available: www.hbr.org/explore 
[8] J. P. Kotter, The Leadership Factor (Free Press 1988) and A force for Change: How Leadership Differs from Management.

[9] L. Achus, Effective Leadership, 3rd ed. Thomson South Western.

[10] E. G. Steffen and R. WaynePace, Powerful Leadership, Downloaded, 2001.

[11] R. L. Daft, “Cengage learning," The Leadership Experience, 2002.

[12] T. L. Greenbaum, the Handbook of Focus Group Research, Lexington Books Revised and Expanded Edition, 1993.

[13] W. H. Peace, The Hard Work of Being A Soft Manager, HBR OnPoint Edition 830x.

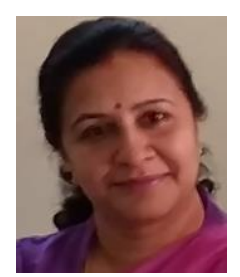

Swaroop Simha studied marketing at Shri Jayachamarajendra College of Engineering Campus, JSS CMS, JSS Science and Technology University, Mysuru. She is an MBA, and Ph.D in marketing management.

Her doctoral theses were in the area of "brand and line extension studies, for consumer durables using qualitative research".

She received a gold medalist and a rank holder both in under graduation and post-graduation from University of Mysore, her career graph includes both Industry (7yrs) and Teaching Academics (17) experience.
Her industry experience is spread over three industries (Computers, Silk Exports and Consumer Electronics), after which, she transitioned to teaching in post graduate and under graduate programs.

Her areas of work include being a teacher of management subjects, corporate trainer, marketing consultant, researcher, and a certified entrepreneurship educator. She has to her credit, published papers in national and international journals and has presented papers at national and international conferences.

She had good experience of teaching in universities in India and abroad, she recently concluded an international teaching assignment at the prestigious College of Banking and Financial Studies in the, Sultanate of Oman where she was closely associated in programs affiliated to Pearson, and Bradford Universities, UK,

A firm believer in creativity and innovation to provide quality life and products for mankind, she is constantly encouraging students to use imagination and creativity to their maximum potential possible. 